\title{
Genetic predisposition for femoral neck stress fractures in military conscripts
}

\author{
Johanna Korvala ${ }^{1 \dagger}$, Heini Hartikka ${ }^{1 \dagger}$, Harri Pihlajamäki ${ }^{2,3}$, Svetlana Solovieva ${ }^{4}$, Juha-Petri Ruohola ${ }^{3}$, Timo Sahi ${ }^{3,5}$, \\ Sandra Barral ${ }^{6}$, Jürg Ott ${ }^{7}$ Leena Ala-Kokko ${ }^{1,8}$, Minna Männikkö ${ }^{1 *}$
}

\begin{abstract}
Background: Stress fractures are a significant problem among athletes and soldiers and may result in devastating complications or even permanent handicap. Genetic factors may increase the risk, but no major susceptibility genes have been identified. The purpose of this study was to search for possible genetic factors predisposing military conscripts to femoral neck stress fractures.

Results: Eight genes involved in bone metabolism or pathology (COLIA1, COLIA2, OPG, ESR1, VDR, CTR, LRP5, IL-6) were examined in 72 military conscripts with a femoral neck stress fracture and 120 controls. The risk of femoral neck stress fracture was significantly higher in subjects with low weight and body mass index (BMI). An interaction between the CTR (rs1801197) minor allele C and the VDR C-A haplotype was observed, and subjects lacking the C allele in CTR and/or the C-A haplotype in VDR had a 3-fold higher risk of stress fracture than subjects carrying both $(\mathrm{OR}=3.22,95 \% \mathrm{Cl}$ 1.38-7.49, $\mathrm{p}=0.007)$. In addition, the LRP5 haplotype A-G-G-C alone and in combination with the VDR haplotype C-A was associated with stress fractures through reduced body weight and BMI.

Conclusions: Our findings suggest that genetic factors play a role in the development of stress fractures in individuals subjected to heavy exercise and mechanical loading. The present results can be applied to the design of future studies that will further elucidate the genetics of stress fractures.
\end{abstract}

\section{Background}

Stress fractures are common and potentially serious exertion injuries, especially among athletes and military conscripts $[1,2]$. Repetitive activities such as running and marching are among the most frequently reported causes, and the approximate incidence of stress fractures in military conscripts ranges from 0.9 to $12.3 \%[3,4]$. Stress fractures occur most commonly in the lower extremities e.g. in the tibia, metatarsals, femur or pelvis, and they manifest as localised pain that increases during exercise.

Femoral neck fractures are one of the most serious high-risk stress fractures, because displaced fatigue fractures of the femoral neck lead to long-term morbidity in a high percentage of patients $[5,6]$. If the fracture is detected quickly and no dislocation has occurred, the

\footnotetext{
* Correspondence: minna.mannikko@oulu.fi

+ Contributed equally

'Oulu Center for Cell-Matrix Research, Biocenter and Department of Medical Biochemistry and Molecular Biology, University of Oulu, Oulu, Finland Full list of author information is available at the end of the article
}

recovery rate is usually good, but displaced femoral neck stress fractures can result in devastating complications or even permanent handicap [5,7].

The pathophysiology of stress fractures is thought to be related to cyclic mechanical loading of the bone, which stimulates an incomplete remodeling response [8]. Bone is continuously degraded and renewed, and inadequate adaptation to mechanical change leads to an imbalance between microdamage and remodeling, and gradually to a fracture. There are numerous risk factors for stress fractures; a Finnish study of male military conscripts reported that tall stature, poor physical fitness, and decreased bone mineral content and bone mineral density (BMD) are factors associated with a greater risk [9].

Several observations suggest that genetic factors contribute to stress fracture susceptibility. Singer and coworkers described multiple identical stress fractures at the same anatomic sites in monozygotic twins after the sixth week of basic training in the army [10], and multiple lower limb stress fractures in the same individual have also been reported [11]. The occurrence of many
Ciomed Central

C 2010 Korvala et al; licensee BioMed Central Ltd. This is an Open Access article distributed under the terms of the Creative Commons Attribution License (http://creativecommons.org/licenses/by/2.0), which permits unrestricted use, distribution, and reproduction in any medium, provided the original work is properly cited. 
stress fractures may also indicate a defective overall bone composition due to genetic factors [12]. Findings in twins and their families suggest that differences in such traits as bone size, shape, and BMD between individuals are largely attributable to genetic differences and not to environmental effects [13].

Mutations or allelic variants in the genes leading to a variety of bone pathologies that increase bone fragility, such as collagen I, (COL1A1 and COL1A2) [14,15], vitamin D receptor $(V D R)$ [16], osteoprotegerin $(O P G)$ [17], calcitonin receptor $(C T R)$ [18], estrogen receptor $(E S R)$ [19], low density lipoprotein receptor-related protein 5 (LRP5) [20], and interleukin 6 (IL-6) [21] may also increase the risk of stress fractures. Sequence variations in these genes are associated with a low peak bone mass, osteoporosis, osteogenesis imperfecta, osteoporosis-pseudoglioma syndrome, and high bone mass, but their role in predisposing to stress fracture is not clear [14-21]. Here we aimed to elucidate the possible role and significance of sequence variations in certain bonerelated genes in the development of femoral neck stress fractures.

\section{Methods}

\section{Subjects}

Femoral neck stress fractures were studied because of the severity and potential consequences of these fractures [5,6]. All military conscripts who had suffered from femoral neck stress fractures and had been treated at the Finnish Defence Forces' military hospitals from 1970 to 1995 were invited to participate in a follow-up examination in 2002 or 2003 . A total of 72 subjects were available for this follow-up. The diagnosis of stress fracture was originally based on accepted radiographic, scintigraphic, or MRI criteria [22,23]. The control group, collected also in the early 2000s, consisted of 120 Finnish conscripts who had not had stress fractures before or during military service, based on their military medical records and a questionnaire. The clinical characteristics of all the subjects are described in Table 1.

Finnish men become eligible for compulsory military service at the age of 18 years, and the duration of required service ranges from 6 to 12 months. Basic

Table 1 Characteristics of cases and controls

\begin{tabular}{llll}
\hline Characteristics & $\begin{array}{l}\text { Cases } \\
\mathbf{n = 7 2}\end{array}$ & $\begin{array}{l}\text { Controls } \\
\mathbf{n = 1 2 0}\end{array}$ & p-value \\
\hline Age & $20.3 \pm 1.6$ & $18.9 \pm 0.5$ & 0.0005 \\
Height & $177.1 \pm 6.0$ & $179.6 \pm 6.2$ & 0.006 \\
Weight & $68.9 \pm 9.6$ & $77.3 \pm 13.1$ & 0.0005 \\
BMl & $22.0 \pm 2.9$ & $23.9 \pm 3.5$ & 0.0005 \\
Smoking (N and \% smokers) & $29(42.0 \%)$ & $67(56.8 \%)$ & 0.069 \\
\hline
\end{tabular}

Data are presented as mean \pm SD training lasts for 6 months and comprises a variety of exercises, ranging from marching, jogging, and cycling to drill and combat training, which involves heavy physical loading.

Information on the background variables was collected from the military medical records, including age, sex, height, weight, and smoking habit. The body mass index (BMI) of each conscript was calculated by dividing the body weight in kilograms by the square of the height in meters $\left(\mathrm{kg} / \mathrm{m}^{2}\right)$. Blood samples were collected from all subjects and controls. All the subjects were males between 18 and 27 years of age at the age of onset. The study was approved by the local ethics committee (Finnish Defence Forces, Helsinki, Finland), and signed informed consent was obtained from each subject.

\section{Scan for mutations in the coding regions of 5 candidate genes}

Genomic DNA was isolated from the blood samples by standard procedures. Polymerase chain reaction amplification of 51 exons of COL1A1, 52 exons of COL1A2, and 23 exons of $L R P 5$ was performed from 72 cases and 120 controls as previously described $[14,20]$. Primers were designed to amplify the 8 exons of $O P G$ and the 5 exons of ESR1 (available on request). The polymerase chain reaction products were scanned for sequence variations by conformation-sensitive gel electrophoresis (CSGE) [14] and products that contained heteroduplexes were sequenced using an ABI PRISM 377 or 3100 Sequencer and the ABI PRISM BigDye Terminator Cycle Sequencing Ready Kit (Applied Biosystems, Foster City, CA).

\section{Genotyping of 15 SNPs in the VDR, CTR, IL-6, COL1A1, COL1A2, and LRP5 genes}

The NCBI GenBank reference numbers and detection methods for each single nucleotide polymorphism (SNP) are shown in Table 2. Genotyping of the VDR, CTR, and $I L-6$ variations was performed as described previously $[16,18,21,24,25]$. Genes that have shown evidence of biological interactions were chosen as candidates for gene-gene interaction analysis [26,27], but only interaction combinations where sample size was large enough were evaluated.

\section{Statistical analysis}

The potential deviation from the Hardy-Weinberg equilibrium was tested using the chi-square test. Disease association studies were performed on alleles and genotypes using the likelihood ratio chi-square test. Variables that differed between the cases and controls and were associated with the polymorphisms were included as covariables in multivariate analyses. Dominant, additive, recessive, and general genetic models were defined and tested for all of the polymorphisms. Haplotype 
Table 2 SNP allele frequencies between cases and controls

\begin{tabular}{|c|c|c|c|c|c|c|}
\hline \multirow[t]{2}{*}{ Gene } & \multirow[t]{2}{*}{ Sequence variation } & \multirow[t]{2}{*}{ Detection method } & \multirow[t]{2}{*}{ Allele } & \multicolumn{2}{|c|}{ Allele frequencies (\%) } & \multirow[t]{2}{*}{ p-value } \\
\hline & & & & Controls & Cases & \\
\hline \multirow[t]{6}{*}{$V D R$} & $\begin{array}{l}\text { c.2T > C, Met1Thr } \\
\text { (rs10735810) }\end{array}$ & Fokl & $C$ & $153(64)$ & $90(62)$ & \\
\hline & & & $\mathrm{T}$ & $87(36)$ & $54(37)$ & NS \\
\hline & $\begin{array}{l}\text { c.1024+283G > A } \\
\text { (rs1544410) }\end{array}$ & Bsml & A & $90(38)$ & $45(31)$ & \\
\hline & & & G & $150(63)$ & $99(69)$ & NS \\
\hline & $\begin{array}{l}\text { c.1056T > C, lle352lle } \\
\text { (rs731236) }\end{array}$ & Taql & C & $88(37)$ & $45(31)$ & \\
\hline & & & $\mathrm{T}$ & $152(63)$ & $99(69)$ & NS \\
\hline \multirow[t]{2}{*}{ IL6 } & $\begin{array}{l}-174 G>C \\
(\mathrm{rs} 1800795)\end{array}$ & Nlalll & C & $126(52.5)$ & $72(50)$ & \\
\hline & & & G & $114(47.5)$ & $72(50)$ & NS \\
\hline \multirow[t]{2}{*}{$C T R$} & $\begin{array}{l}\text { c.1377C > T, Pro463Leu } \\
\text { (rs1801197) }\end{array}$ & Alul & C & $73(30)$ & $35(24)$ & \\
\hline & & & $\mathrm{T}$ & $167(70)$ & $109(76)$ & NS \\
\hline \multirow[t]{6}{*}{ COLIA1 } & $\begin{array}{l}\text { c. } 101+1024 G>T \\
\text { (rs1800012) }\end{array}$ & Sequencing & G & $204(85)$ & $123(85)$ & \\
\hline & & & $\mathrm{T}$ & $36(15)$ & $21(15)$ & NS \\
\hline & $\begin{array}{l}\text { C.1930-14T > C } \\
\text { (rs2696247) }\end{array}$ & CSGE & C & $41(17)$ & $28(19)$ & \\
\hline & & & $\mathrm{T}$ & $199(83)$ & $116(81)$ & NS \\
\hline & $\begin{array}{l}\text { c.3261C > T } \\
\text { (rs2586488) }\end{array}$ & Eco57l & C & $158(66)$ & $87(60)$ & \\
\hline & & & $\mathrm{T}$ & $82(34)$ & $57(40)$ & NS \\
\hline \multirow[t]{6}{*}{ COLIA2 } & $\begin{array}{l}\text { c.280-68A > G } \\
\text { (rs406226) }\end{array}$ & CSGE & A & $206(86)$ & $120(83)$ & \\
\hline & & & G & $34(14)$ & $24(17)$ & NS \\
\hline & $\begin{array}{l}\text { c. } 1666-41 G>A \\
(\mathrm{rs} 2301643)\end{array}$ & Msll & A & $32(13)$ & $24(17)$ & \\
\hline & & & G & $208(87)$ & $120(83)$ & NS \\
\hline & $\begin{array}{l}\text { c.2350-89ins38bp } \\
\text { (rs3216902) }\end{array}$ & CSGE & insertion & $151(63)$ & $96(67)$ & \\
\hline & & & no ins. & $89(37)$ & $48(33)$ & NS \\
\hline \multirow[t]{8}{*}{ LRP5 } & $\begin{array}{l}\text { c. } 2007 \mathrm{G}>\mathrm{A}, \mathrm{E} 644 \mathrm{E} \\
\text { (rs2277268) }\end{array}$ & Sequencing & G & $231(96)$ & 131 (91) & \\
\hline & & & A & $9(4)$ & $13(9)$ & $0.031^{1}$ \\
\hline & $\begin{array}{l}\text { c.2074G > A, V667M } \\
\text { (rs4988321) }\end{array}$ & Sequencing & G & 235 (98) & 137 (95) & \\
\hline & & & A & $5(2)$ & $7(5)$ & NS \\
\hline & $\begin{array}{l}\text { c.3432A > G, V1119V } \\
\text { (rs556442) }\end{array}$ & Sequencing & A & $200(83)$ & $112(78)$ & \\
\hline & & & G & $40(17)$ & $32(22)$ & NS \\
\hline & $\begin{array}{l}\text { c.4064C > T, A1330V } \\
\text { (rs3736228) }\end{array}$ & Sequencing & $C$ & 227 (95) & 134 (93) & \\
\hline & & & $\mathrm{T}$ & $13(5)$ & $10(7)$ & NS \\
\hline
\end{tabular}

NS = not significant; GenBank Accession numbers COL1A1 NM_000088, COL1A2 NM_000089, VDR NM_000376, LRP5 NM_002335, CTR NM_001742; ${ }^{\text {NSS }}$ permutation $\mathrm{p}$-value, $\mathrm{p}=0.21$.

frequencies and pair-wise linkage disequilibrium (D') and correlation coefficient $\left(\mathrm{r}^{2}\right)$ values were established using Haploview software (MIT/Harvard Broad Institute Cambridge, MA) [28]. The haplotypes were reconstructed statistically from population genotype data using the PHASE program with the Markov chain method for haplotype assignment [29]. Potential risk or protective haplotypes were identified by comparing haplotype frequencies between the cases and controls using Fisher's exact probability test or the chi-square test. The robustness of the associations was evaluated with permutation tests (100 permutations). 
Crude and adjusted odds ratios and their 95\% confidence intervals (CIs) were calculated using the SPSS statistical package (SPSS, Chicago, IL), and interactions between the polymorphisms were investigated by stratification and logistic regression analysis. The statistical significance of a $p$-value was defined as the $5 \%$ level.

\section{Results}

\section{Clinical findings}

The basic characteristics of the cases and controls were compared and are shown on Table 1 . The results indicated that the cases were smaller in size than the controls; i.e., they were shorter and had lower body weight and BMI. As the control group data were collected at a later time than those for the stress fracture patients, the height, weight, and BMI were also compared to those of healthy contemporaries of the cases. The findings were the same in that body weight and BMI were lower in cases than in their healthy contemporaries, indicating that the time discrepancy between controls and cases did not account for the differences in these parameters (data not shown). Unfortunately, DNA was not available for genetic analyses of the contemporary subjects. The risk of femoral neck stress fractures was significantly higher in subjects with low body weight and low BMI. The control group differed from the cases in regard to age, but no statistically significant association between age and BMI or BMI and smoking between control group and cases was detected (data not shown).

\section{Candidate gene analysis}

Because sequence variations in COL1A1, COL1A2, $L R P 5, O P G$, and ESR1 increase the risk of low bone mass or osteoporotic fractures, we first examined their possible role in the pathogenesis of stress fractures by scanning all their exons and exon boundaries in the 72 subjects and the 120 controls for mutations using CSGE $[14,15,17,20]$. The analysis revealed no putative diseasecausing mutations. Several sequence variations were observed in these genes, but none of them was novel (as verified from the NCBI GenBank), and they were all detected in both stress fracture subjects and controls (data not shown).

\section{Association analyses of SNPs}

To test for possible allelic associations, a total of 15 SNPs in 6 genes (COL1A1, COL1A2, CTR, IL-6, VDR, and $L R P 5)$ were genotyped. The genotype frequencies for 15 SNPs were all in Hardy-Weinberg equilibrium. A comparison of the resulting allele frequencies between the cases and controls (Table 2) suggested that the frequency of the LRP5 rs2277268 minor allele A was marginally elevated in the cases. The same allele was significantly associated with both low body weight (A:
$68.6 \pm 9.0 \mathrm{~kg}$ vs. $\mathrm{G}: 74.5 \pm 12.7 \mathrm{~kg}, \mathrm{p}=0.036)$ and low BMI (A: $21.5 \pm 2.5 \mathrm{~kg} / \mathrm{m}^{2}$ vs. G: $23.3 \pm 3.4 \mathrm{~kg} / \mathrm{m}^{2}$, $\mathrm{p}=$ 0.017). In addition, the LRP5 rs4988321 minor allele A was associated with lower height (A: $175.6 \pm 4.6 \mathrm{~cm}$ vs. G: $178.8 \pm 6.2 \mathrm{~cm}, \mathrm{p}=0.025)$, and the $V D R B s m \mathrm{I}$ minor allele A was associated with higher BMI (A: $23.7 \pm 3.7$ $\mathrm{kg} / \mathrm{m}^{2}$ vs. $\left.\mathrm{G}: 22.9 \pm 3.2 \mathrm{~kg} / \mathrm{m}^{2}, \mathrm{p}=0.04\right)$. Because neither of the polymorphisms was associated with either age or smoking, only BMI was included as a covariate in the subsequent analyses.

The COL1A1 rs2586488 and COL1A2 rs3216902 SNPs were associated with stress fractures in a recessive model (Table 3), and the risk was increased in carriers of the LRP5 rs2277268 minor allele in comparison with non-carriers $(\mathrm{OR}=2.72 ; 95 \% \mathrm{CI} 1.10-6.73, \mathrm{p}=0.03)$. After adjusting for BMI, however, the observed associations lost their statistical significance. $V D R, C T R$, and $I L-6$ SNPs, did not significantly associate with stress fracture in any genetic model (Table 3 ).

\section{Linkage disequilibrium, haplotype and interaction analyses}

The pairwise linkage disequilibrium between the SNPs within each gene was estimated in terms of $D^{\prime}$ and $r^{2}$. A linkage disequilibrium plot for the $V D R, C O L 1 A 1$, COL1A2, and LRP5 SNPs is presented in Figures 1A-D. The SNPs within the COL1A1 and COL1A2 genes were in linkage disequilibrium (Figure 1). Of the eight COL1A2 haplotypes derived from the analysis, three were common in both cases and controls, but four rare haplotypes were detected only in controls. The COL1A2 haplotype frequencies were marginally different between the cases and controls ( $\mathrm{p}=0.0197$, data not shown). The association of the phenotype with the COL1A1 haplotypes was not significant. In the case of the VDR gene, the FokI (rs10735810) and the TaqI-BsmI (rs731236 \& rs1544410) SNPs were located in two different haplotype blocks. No association between the VDR haplotypes and stress fractures was detected.

Seven haplotypes were detected in the LRP5 gene. The A-G-G-C haplotype frequency was higher among cases than among controls $(\mathrm{p}=0.031)$, and the risk of stress fractures was higher among its carriers than in non-carriers (OR 2.72; 95\% CI 1.10 - 6.73). On the other hand, the A-G-G-C haplotype increased the risk of low BMI (OR 2.50; 95 \% CI 1.03-6.07, p = 0.04), so the association between haplotype and stress fracture lost its statistical significance after adjusting for BMI (OR 2.04; 95\% CI 0.79 - 5.22), suggesting that BMI mediates this association.

Interactions between the CTR-VDR, VDR-LRP5 and $C T R-V D R-L R P 5$ genes were examined. Their contribution to the risk for stress fractures revealed an interaction between the LRP5 haplotype A-G-G-C and the 
Table 3 Genotype distributions, odds ratios (OR), and their $95 \%$ confidence intervals ( $\mathrm{Cl}$ ) and p-values for the genetic models

\begin{tabular}{|c|c|c|c|c|c|c|c|c|c|}
\hline \multirow[b]{2}{*}{ Gene } & \multirow[b]{2}{*}{ SNPs ID } & \multirow[b]{2}{*}{ Genotype } & \multirow[b]{2}{*}{$\begin{array}{c}\text { Counts } \\
\text { (Controls/Cases) }\end{array}$} & \multirow[b]{2}{*}{ OR } & \multirow[b]{2}{*}{$95 \% \mathrm{Cl}$} & \multicolumn{4}{|c|}{ p-value } \\
\hline & & & & & & General association & Dominant & Additive & Recessive \\
\hline \multirow[t]{9}{*}{$\overline{V D R}$} & rs10735810 & $\mathrm{C} / \mathrm{C}$ & $41 / 29$ & 1 & & 0.24 & 0.57 & 0.80 & 0.18 \\
\hline & & $\mathrm{T} / \mathrm{C}$ & $58 / 30$ & 0.71 & $0.38-1.35$ & & & & \\
\hline & & $\mathrm{T} / \mathrm{T}$ & $11 / 10$ & 1.50 & $0.60-3.78$ & & & & \\
\hline & rs1544410 & $\mathrm{G} / \mathrm{G}$ & $46 / 17$ & 1 & & 0.15 & 0.08 & 0.22 & 0.91 \\
\hline & & $\mathrm{G} / \mathrm{A}$ & $58 / 25$ & 0.54 & $0.28-1.01$ & & & & \\
\hline & & $\mathrm{A} / \mathrm{A}$ & $16 / 10$ & 0.78 & $0.32-1.91$ & & & & \\
\hline & rs731236 & $\mathrm{T} / \mathrm{T}$ & $49 / 37$ & 1 & & 0.32 & 0.15 & 0.30 & 0.96 \\
\hline & & $\mathrm{T} / \mathrm{C}$ & $54 / 25$ & 0.61 & $0.32-1.16$ & & & & \\
\hline & & $\mathrm{C} / \mathrm{C}$ & $17 / 10$ & 0.78 & $0.32-1.90$ & & & & \\
\hline \multirow[t]{3}{*}{ IL6 } & rs1800795 & $\mathrm{G} / \mathrm{G}$ & $35 / 15$ & 1 & & 0.27 & 0.20 & 0.63 & 0.59 \\
\hline & & $\mathrm{G} / \mathrm{C}$ & $56 / 42$ & 1.75 & $0.85-3.61$ & & & & \\
\hline & & $\mathrm{C} / \mathrm{C}$ & 29/15 & 1.21 & $0.51-2.88$ & & & & \\
\hline \multirow[t]{3}{*}{ CTR } & rs1922295 & $\mathrm{T} / \mathrm{T}$ & $59 / 45$ & 1 & & 0.12 & 0.07 & 0.22 & 0.81 \\
\hline & & $\mathrm{T} / \mathrm{C}$ & $49 / 19$ & 0.51 & $0.25-0.98$ & & & & \\
\hline & & $\mathrm{C} / \mathrm{C}$ & $12 / 8$ & 0.87 & $0.33-2.32$ & & & & \\
\hline \multirow[t]{8}{*}{ COLIA1 } & rs1800012 & $\mathrm{G} / \mathrm{G}$ & $85 / 53$ & 1 & & 0.48 & 0.68 & 0.91 & 0.30 \\
\hline & & $\mathrm{G} / \mathrm{T}$ & $34 / 17$ & 0.80 & $0.41-1.58$ & & & & \\
\hline & & $\mathrm{T} / \mathrm{T}$ & $1 / 2$ & 3.21 & $0.28-36.25$ & & & & \\
\hline & rs2696247 & $\mathrm{T} / \mathrm{T}$ & 189/100 & 1 & & 0.45 & - & - & - \\
\hline & & $\mathrm{T} / \mathrm{C}$ & $123 / 88$ & 1.27 & $0.68-2.35$ & & & & \\
\hline & rs2586488 & $\mathrm{C} / \mathrm{C}$ & $50 / 30$ & 1 & & 0.09 & 1.0 & 0.30 & $0.04^{1}$ \\
\hline & & $\mathrm{C} / \mathrm{T}$ & $58 / 27$ & 0.78 & $0.41-1.48$ & & & & \\
\hline & & $T / T$ & $12 / 15$ & 2.08 & $0.86-5.04$ & & & & \\
\hline \multirow[t]{9}{*}{ COL1A2 } & rs406226 & $\mathrm{A} / \mathrm{A}$ & $86 / 50$ & 1 & & 0.14 & 0.74 & 0.49 & - \\
\hline & & $\mathrm{A} / \mathrm{G}$ & $34 / 20$ & 1.01 & $0.53-1.94$ & & & & \\
\hline & & $\mathrm{G} / \mathrm{G}$ & $0 / 2$ & - & - & & & & \\
\hline & rs2301643 & $\mathrm{G} / \mathrm{G}$ & $88 / 50$ & 1 & & 0.13 & 0.56 & 0.35 & - \\
\hline & & $\mathrm{G} / \mathrm{A}$ & $32 / 20$ & 1.10 & $0.57-2.12$ & & & & \\
\hline & & $\mathrm{A} / \mathrm{A}$ & $0 / 2$ & - & - & & & & \\
\hline & rs3216902 & Ins/Ins & $52 / 29$ & 1 & & 0.05 & 0.68 & 0.46 & $0.03^{2}$ \\
\hline & & Ins/Nol & $47 / 38$ & 1.45 & $0.78-2.71$ & & & & \\
\hline & & $\mathrm{Nol} / \mathrm{Nol}$ & $21 / 5$ & 0.43 & $0.15-1.25$ & & & & \\
\hline \multirow[t]{9}{*}{ LRP5 } & rs2277268 & $\mathrm{G} / \mathrm{G}$ & $111 / 59$ & 1 & & 0.03 & - & - & - \\
\hline & & $\mathrm{G} / \mathrm{A}$ & $9 / 13$ & 2.72 & $1.10-6.73$ & & & & \\
\hline & rs4988321 & $\mathrm{G} / \mathrm{G}$ & $115 / 65$ & 1 & & 0.13 & - & - & - \\
\hline & & $\mathrm{G} / \mathrm{A}$ & $5 / 7$ & 2.48 & $0.76-8.12$ & & & & \\
\hline & rs556442 & $\mathrm{A} / \mathrm{A}$ & $82 / 43$ & 1 & & 0.36 & 0.23 & 0.17 & 0.30 \\
\hline & & $\mathrm{A} / \mathrm{G}$ & $36 / 26$ & 1.38 & $0.74-2.57$ & & & & \\
\hline & & $G / G$ & $2 / 3$ & 2.86 & $0.46-17.78$ & & & & \\
\hline & rs3736228 & $\mathrm{C} / \mathrm{C}$ & $107 / 62$ & 1 & & 0.53 & - & - & - \\
\hline & & $\mathrm{C} / \mathrm{T}$ & $13 / 100$ & 1.33 & $0.55-3.21$ & & & & \\
\hline
\end{tabular}

${ }^{1} \mathrm{OR}=2.37,95 \% \mathrm{Cl} 1.04-5.40 .{ }^{2} \mathrm{OR}=0.35,95 \% \mathrm{Cl} 0.13-0.98$. Body mass index (BMI) was used as a covariate in the analyses.

$V D R$ haplotype C-A (Table 4); i.e., the risk of femoral neck fracture was marginally increased in subjects without the C-A haplotype (OR 1.78; 95\% CI 0.96 - 3.30), and increased 3.85-fold (95\% CI: 1.16-12.84) in carriers of both the A-G-G-C and C-A haplotypes compared with carriers of only the C-A haplotype. The associations were attenuated after adjustment for BMI (OR 3.10; $95 \%$ CI $0.87-11.1$ for a joint effect of haplotypes) suggesting, that $\mathrm{BMI}$ at least partly mediates the joint effect of the A-G-G-C and C-A haplotypes on stress 

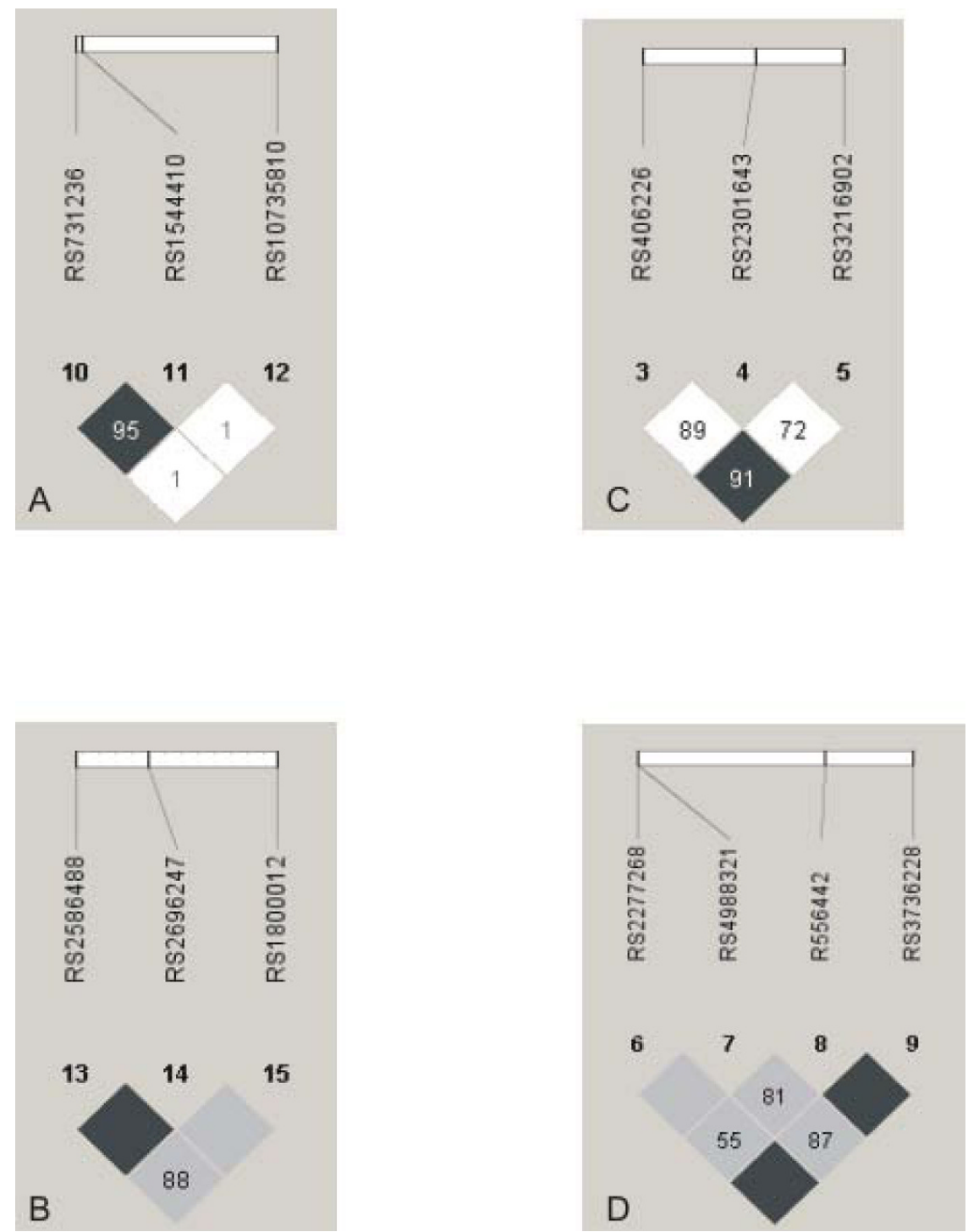

Figure 1 A) Haploview linkage disequilibirum (LD) plot of the VDR SNPs, B) Haploview LD plot of the COL1A1 SNPs, C) Haploview LD plot of the COL1A2 SNPs, and D) Haploview LD plot of the LRP5 SNPs. D' values are indicated in the figure.

fracture. The most significant finding of the present study was the observed interaction between a CTR minor allele $\mathrm{C}$ and the $V D R \mathrm{C}$-A haplotype, the risk of fracture being significantly increased in subjects without

Table 4 LRP5 A-G-G-C haplotype and VDR C-A haplotype interaction

\begin{tabular}{ccccccccc}
\hline LRP5 & VDR & \multicolumn{2}{c}{ Controls } & \multicolumn{2}{c}{ Cases } & & \\
\cline { 3 - 6 } A-G-G-C & C-A & N & fr. & N & fr. & OR $(\mathbf{9 5 \%}$ Cl) & p-value \\
\hline- or + & - & 50 & 0.383 & 37 & 0.444 & $1.78(0.96-3.30)^{1}$ & 0.07 \\
- & + & 65 & 0.542 & 27 & 0.375 & 1.00 & \\
+ & + & 5 & 0.042 & 8 & 0.111 & $\mathbf{3 . 8 5}(\mathbf{1 . 1 6 - 1 2 . 8 4})^{\mathbf{2}}$ & $\mathbf{0 . 0 2 8}$
\end{tabular}

${ }^{1} 1.85$ (0.96-3.55) after adjustment for body mass index (BMI)

23.10 (0.87-11.1) after adjustment for body mass index (BMI) the $\mathrm{C}$ allele or the $\mathrm{C}$-A haplotype or without either one $(\mathrm{OR}=3.22,95 \%$ CI 1.38-7.49, $\mathrm{p}=0.007)$ in comparison with carriers of both.

\section{Discussion}

The significance of physical and mechanical risk factors in the development of stress fractures is well established [9]. The present findings indicate that genetic factors may also play a role in the development of femoral neck stress fractures. We found an interaction between the CTR C allele and the VDR C-A haplotype, and the risk of stress fractures was 3-fold higher in military conscripts lacking either one or both compared to carriers of both. In addition, the LRP5 gene haplotype A-G-G-C conferred almost a 3 -fold increased risk for developing 
femoral neck stress fractures, and a 4-fold increased risk in combination with the VDR C-A haplotype, although these associations were mediated by low body weight and $\mathrm{BMI}$ and require further investigation.

Because of the important role of CTR in bone homeostasis, polymorphisms of this gene have been studied with regard to common bone parameters and disorders. Several studies report an association between the CTR polymorphism AluI and lumbar spine and femoral neck BMD in both men and women, but the reports have been somewhat contradictory. Studies in postmenopausal women revealed that the CC genotype is more common in non-osteoporotic women than the TT genotype $[30,31]$, and that the TT genotype is associated with lower lumbar spine and femoral neck BMD and increases the predisposition for osteoporosis [32,33]. The opposite finding was suggested by Braga et al. [34] who reported that the $\mathrm{CC}$ genotype is associated with decreased BMD and is more common in men with hip or vertebral fractures than in control subjects [34]. In our study, the CTR allele $\mathrm{C}$ together with a VDR C-A haplotype appeared to protect subjects from fractures.

Polymorphisms in CTR and VDR are associated with BMD in Spanish women [35]. The observed interaction between a $C T R$ minor allele and the VDR C-A haplotype and their association with stress fractures may be explained by the inhibitory effect of these proteins on parathyroid hormone production. CTR and VDR are both involved in sustaining normocalcemia by inhibiting the production of parathyroid hormone [36]. The observed allele-haplotype interaction may have an effect on the regulatory role of the proteins and therefore on control of $\mathrm{Ca}$ levels.

VDR also has independent effects on bone biology and may play a role in bone pathologies such as stress fractures. VDR is essential for $1,25(\mathrm{OH})_{2} \mathrm{D}_{3}$ to induce the calcemic and phosphatemic effects that normally result in bone mineralization and remodelling [37]. VDR genotypes increase the risk for low BMD and osteoporotic fractures [16,38] and $V D R$ knock-out mice develop a low bone mass phenotype with hypocalcemia, hypophosphatemia, and elevated $1,25(\mathrm{OH})_{2} \mathrm{D}_{3}$ levels [39]. In addition, reduced serum 25(OH)D levels might predispose young men to stress fractures [40].

The present study indicates that the association of the $L R P 5$ haplotype and LRP5-VDR interaction with stress fractures is mediated by low body weight and BMI, but more research is needed before any definitive conclusions can be drawn from these findings. The function of LRP5 in bone development, however, is indisputable [41]; mutations in LRP5 cause various bone disorders $[20,42]$ and polymorphisms are associated with BMD and bone mineral content in general [43], but also with reduced BMD and fractures [44]. Mouse studies demonstrated that mutations in $\operatorname{Lrp} 5$ affect bone formation sensitivity in response to normal mechanical loading $[45,46]$, and thus the LRP5 haplotype A-G-G-C might affect bone sensitivity and response to mechanical loading. It is possible that bone in the lighter-weight conscripts is initially adjusted to lower load bearing and when mechanical loading sharply increases in the military service, the genetically set response might not adjust rapidly enough to react to the increased loading, thus putting lighter weight conscripts at higher risk for stress fractures. Our results support earlier findings that low weight (before and/or during military service) increases the risk of stress fractures $[3,47]$. Body weight is an important predictor of BMD [48], and BMI and obesity have been shown in a family-based analysis to be associated with LRP5 polymorphisms [49], underlining the role of LRP5 also in weight regulation.

One limitation of the present study is the discrepancy in the collection periods of case and control groups. The most important physical variable was weight, because reduced weight and BMI mediate the association of the LRP5 haplotype and the LRP5-VDR interaction with femoral neck stress fractures. Interestingly, however, the same difference in weight and BMI was also observed between the cases and their healthy contemporaries, suggesting that the difference was not time-dependent. This verification is important because the mean BMI and the number of overweight conscripts has consistently increased towards the end of $20^{\text {th }}$ century, whereas the physical fitness of conscripts has declined [50]. Unfortunately, other extrinsic factors that could have changed during the 30 years scale (e.g. in nutrition or exercise) have not been examined because of the limited amount of information available. The results of the study should be interpreted with moderation and replication of the study is needed to confirm the present findings. For future studies, larger sample sizes are desirable to gain more statistical power in the analyses. In addition, functional studies on the present genetic findings are needed to elucidate the relevance of these genetic associations to femoral neck stress fractures.

\section{Conclusions}

Our findings suggest that genetic factors may play a role in the development of stress fractures in individuals subjected to heavy exercise and mechanical loading. The present results can be applied to the design of future studies that will further elucidate the genetics of stress fractures.

\section{Acknowledgements}

We wish to thank all the conscripts who volunteered for this study. We thank Mrs. Aira Erkkilä and Mrs. Irma Vuoti for their expert technical 
assistance. This work was supported by grants from the Academy of Finland (to L.A.K.), the Scientific Committee of the Finnish Defence Forces (to H.P.), the Natural Science Foundation of China (project no. 30730057 to J.O.), and the Finnish Cultural Foundation (to H.H.).

\section{Author details}

Oulu Center for Cell-Matrix Research, Biocenter and Department of Medical Biochemistry and Molecular Biology, University of Oulu, Oulu, Finland. ${ }^{2}$ Department of Orthopaedic Surgery, National Military Hospital, Helsinki, Finland. ${ }^{3}$ Centre for Military Medicine, Research Department, Helsinki, Finland. ${ }^{4}$ Centre of Expertise for Health and Work Ability, Finnish Institute of Occupational Health, Helsinki, Finland. ${ }^{5}$ Department of Public Health, University of Helsinki, Helsinki, Finland. ${ }^{6}$ Gertrude H. Sergievsky Center, College for Physicians and Surgeons, Columbia University, New York, USA. ${ }^{7}$ Beijing Institute of Genomics, Chinese Academy of Sciences, Beijing, China. ${ }^{8}$ Connective Tissue Gene Tests, Allentown, PA, USA

\section{Authors' contributions}

$\mathrm{JK}$ and $\mathrm{HH}$ carried out molecular genetic studies and drafted the manuscript. SS and SB performed the statistical analyses. HP, JPR, TS, JO, LAK and MM conceived of the study, participated in its design and coordination and helped to draft the manuscript. All authors read and approved the manuscript.

Received: 8 June 2010 Accepted: 21 October 2010 Published: 21 October 2010

\section{References}

1. Ha Kl, Hahn SH, Chung MY, Yang BK, Yi SR: A clinical study of stress fractures in sports activities. Orthopedics 1991, 14:1089-1095.

2. Sterling JC, Edelstein DW, Calvo RD, Webb R: Stress fractures in the athlete. Diagnosis and management. Sports Med 1992, 14:336-346.

3. Brudvig TJ, Gudger TD, Obermeyer L: Stress fractures in 295 trainees: a one-year study of incidence as related to age, sex, and race. Mil Med 1983, 148:666-667.

4. Sahi T: Stress fractures. Revue Internationale de Services de Sante, des Armees de Terre, de Mer et de l'Air 1984, 57:311-313.

5. Pihlajamäki HK, Ruohola JP, Kiuru MJ, Visuri TI: Displaced femoral neck fatigue fractures in military recruits. J Bone Joint Surg (Am) 2006, 88:1989-1997.

6. Boden BP, Osbahr DC: High-risk stress fractures: evaluation and treatment. J Am Acad Orthop Surg 2000, 8:344-353.

7. Weistroffer JK, Muldoon MP, Duncan DD, Fletcher EH, Padgett DE: Femoral neck stress fractures: outcome analysis at minimum five-year follow-up. J Orthop Trauma 2003, 17:334-337.

8. Markey KL: Stress fractures. Clin Sports Med 1987, 6:405-425.

9. Välimäki W, Alfthan $H$, Lehmuskallio E, Löyttyniemi E, Sahi T, Suominen $H$, Välimäki MJ: Risk factors for clinical stress fractures in male military recruits: a prospective cohort study. Bone 2005, 37:267-273.

10. Singer A, Ben-Yehuda O, Ben-Ezra Z, Zaltzman S: Multiple identical stress fractures in monozygotic twins. Case report. J Bone Joint Surg (Am) 1990, 72:444-445.

11. Lambros G, Alder D: Multiple stress fractures of the tibia in a healthy adult. Am J Orthop 1997, 26:687-688.

12. Friedman E, Vered I, Shemer J: The genetic basis for stress fractures. In Musculoskeletal fatigue and stress fractures. Edited by: Burr DB, Milgrom C. Florida, USA: CRC Press LLC; 2001:105-117.

13. Nguyen TV, Eisman JA: Genetics of fracture: challenges and opportunities. J Bone Miner Res 2000, 15:1253-1256.

14. Körkkö J, Ala-Kokko L, De Paepe A, Nuytinck L, Earley J, Prockop DJ: Analysis of the COL1A1 and COL1A2 genes by PCR amplification and scanning by conformation-sensitive gel electrophoresis identifies only COL1A1 mutations in 15 patients with osteogenesis imperfecta type I: identification of common sequences of null-allele mutations. Am J Hum Genet 1998, 62:98-110.

15. Uitterlinden AG, Burger $H$, Huang Q, Yue F, McGuigan FE, Grant SF, Hofman A, van Leeuwen JP, Pols HA, Ralston SH: Relation of alleles of the collagen type lalpha1 gene to bone density and the risk of osteoporotic fractures in postmenopausal women. N Engl J Med 1998, 338:1016-1021.
16. Morrison NA, Qi JC, Tokita A, Kelly PJ, Crofts L, Nguyen TV, Sambrook PN, Eisman JA: Prediction of bone density from vitamin $D$ receptor alleles. Nature 1994, 367:284-287.

17. Simonet WS, Lacey DL, Dunstan CR, Kelley M, Chang MS, Luthy R, Nguyen $\mathrm{HQ}$, Wooden S, Bennett L, Boone T, Shimamoto G, DeRose M, Elliott R, Colombero A, Tan HL, Trail G, Sullivan J, Davy E, Bucay N, Renshaw-Gegg L, Hughes TM, Hill D, Pattison W, Campbell P, Sander S, Van G, Tarpley J, Derby P, Lee R, Boyle WJ: Osteoprotegerin: a novel secreted protein involved in the regulation of bone density. Cell 1997, 89:309-319.

18. Nakamura $M$, Morimoto $S$, Zhang Z, Utsunomiya $H$, Inagami $T$, Ogihara $T$, Kakudo K: Calcitonin receptor gene polymorphism in japanese women: correlation with body mass and bone mineral density. Calcif Tissue Int 2001, 68:211-215.

19. Langdahl BL, Lokke E, Carstens M, Stenkjaer LL, Eriksen EF: A TA repeat polymorphism in the estrogen receptor gene is associated with osteoporotic fractures but polymorphisms in the first exon and intron are not. J Bone Miner Res 2000, 15:2222-2230.

20. Gong Y, Slee RB, Fukai N, Rawadi G, Roman-Roman S, Reginato AM, Wang H, Cundy T, Glorieux FH, Lev D, Zacharin M, Oexle K, Marcelino J, Suwairi W, Heeger S, Sabatakos G, Apte S, Adkins WN, Allgrove J, ArslanKirchner M, Batch JA, Beighton P, Black GC, Boles RG, Boon LM, Borrone C, Brunner HG, Carle GF, Dallapiccola B, De Paepe A, Floege B, Halfhide ML, Hall B, Hennekam RC, Hirose T, Jans A, Juppner H, Kim CA, KepplerNoreuil K, Kohlschuetter A, LaCombe D, Lambert M, Lemyre E, Letteboer T, Peltonen L, Ramesar RS, Romanengo M, Somer H, Steichen-Gersdorf E, Steinmann B, Sullivan B, Superti-Furga A, Swoboda W, van den Boogaard MJ, Van Hul W, Vikkula M, Votruba M, Zabel B, Garcia T, Baron R, Olsen BR, Warman ML, Osteoporosis-Pseudoglioma Syndrome Collaborative Group: LDL receptor-related protein 5 (LRP5) affects bone accrual and eye development. Cell 2001, 107:513-523.

21. Lorentzon M, Lorentzon R, Nordstrom P: Interleukin-6 gene polymorphism is related to bone mineral density during and after puberty in healthy white males: a cross-sectional and longitudinal study. J Bone Miner Res 2000, 15:1944-1949.

22. Anderson MW, Greenspan A: Stress fractures. Radiology 1996, 199:1-12.

23. Kiuru MJ, Pihlajamäki HK, Ahovuo JA: Bone stress injuries. Acta Radiol 2004, 45:317-326.

24. Gross C, Eccleshall TR, Malloy PJ, Villa ML, Marcus R, Feldman D: The presence of a polymorphism at the translation initiation site of the vitamin $D$ receptor gene is associated with low bone mineral density in postmenopausal Mexican-American women. J Bone Miner Res 1996, 11:1850-1855.

25. Riggs BL, Nguyen TV, Melton LJ, Morrison NA, O'Fallon WM, Kelly PJ, Egan KS, Sambrook PN, Muhs JM, Eisman JA: The contribution of vitamin $D$ receptor gene alleles to the determination of bone mineral density in normal and osteoporotic women. J Bone Miner Res 1995, 10:991-996.

26. Fretz JA, Zella LA, Kim S, Shevde NK, Pike JW: 1,25-Dihydroxyvitamin D3 regulates the expression of low-density lipoprotein receptor-related protein 5 via deoxyribonucleic acid sequence elements located downstream of the start site of transcription. Mol Endocrinol 2006, 20:2215-2230.

27. Peleg S, Abruzzese RV, Cooper CW, Gagel RF: Down-regulation of calcitonin gene transcription by vitamin $D$ requires two widely separated enhancer sequences. Mol Endocrinol 1993, 7:999-1008.

28. Barrett JC, Fry B, Maller J, Daly MJ: Haploview: analysis and visualization of LD and haplotype maps. Bioinformatics 2005, 21:263-265.

29. Stephens M, Smith NJ, Donnelly P: A new statistical method for haplotype reconstruction from population data. Am J Hum Genet 2001, 68:978-989.

30. Masi L, Becherini L, Gennari L, Colli E, Mansani R, Falchetti A, Cepollaro C, Gonnelli S, Tanini A, Brandi ML: Allelic variants of human calcitonin receptor: distribution and association with bone mass in postmenopausal Italian women. Biochem Biophys Res Commun 1998, 245:622-626.

31. Nakamura M, Zhang ZQ, Shan L, Hisa T, Sasaki M, Tsukino R, Yokoi T, Kaname A, Kakudo K: Allelic variants of human calcitonin receptor in the Japanese population. Hum Genet 1997, 99:38-41.

32. Masi L, Becherini L, Colli E, Gennari L, Mansani R, Falchetti A, Becorpi AM, Cepollaro C, Gonnelli S, Tanini A, Brandi ML: Polymorphisms of the calcitonin receptor gene are associated with bone mineral density in 
postmenopausal Italian women. Biochem Biophys Res Commun 1998, 248:190-195.

33. Tsai FJ, Chen WC, Chen HY, Tsai CH: The ALUI calcitonin receptor gene polymorphism (TT) is associated with low bone mineral density and susceptibility to osteoporosis in postmenopausal women. Gynecol Obstet Invest 2003, 55:82-87

34. Braga V, Sangalli A, Malerba G, Mottes M, Mirandola S, Gatti D, Rossini M, Zamboni M, Adami S: Relationship among VDR (Bsml and Fokl), COLIA1, and CTR polymorphisms with bone mass, bone turnover markers, and sex hormones in men. Calcif Tissue Int 2002, 70:457-462.

35. Bandres E, Pombo I, Gonzalez-Huarriz M, Rebollo A, Lopez G, GarciaFoncillas J: Association between bone mineral density and polymorphisms of the VDR, ERalpha, COL1A1 and CTR genes in Spanish postmenopausal women. J Endocrinol Invest 2005, 28:312-321.

36. Garfia B, Canadillas S, Canalejo A, Luque F, Siendones E, Quesada M, Almaden $Y$, Aguilera-Tejero E, Rodriguez M: Regulation of parathyroid vitamin D receptor expression by extracellular calcium. J Am Soc of Nephrol 2002, 13:2945-2952.

37. Haussler MR, Whitfield GK, Haussler CA, Hsieh JC, Thompson PD, Selznick SH, Dominguez CE, Jurutka PW: The nuclear vitamin D receptor: biological and molecular regulatory properties revealed. J Bone Miner Res 1998, 13:325-349.

38. Uitterlinden $A G$, Weel $A E$, Burger $H$, Fang $Y$, van Duijn $C M$, Hofman $A$, van Leeuwen JP, Pols HA: Interaction between the vitamin $D$ receptor gene and collagen type lalpha1 gene in susceptibility for fracture. J Bone Miner Res 2001, 16:379-385

39. Yoshizawa $T$, Handa $Y$, Uematsu $Y$, Takeda $S$, Sekine $K$, Yoshihara $Y$, Kawakami T, Arioka K, Sato H, Uchiyama Y, Masushige S, Fukamizu A, Matsumoto T, Kato S: Mice lacking the vitamin D receptor exhibit impaired bone formation, uterine hypoplasia and growth retardation after weaning. Nat Genet 1997, 16:391-396.

40. Ruohola JP, Laaksi I, Ylikomi T, Haataja R, Mattila VM, Sahi T, Tuohimaa P, Pihlajamäki H: Association between serum 25(OH)D concentrations and bone stress fractures in Finnish young men. J Bone Miner Res 2006, 21:1483-1488.

41. Westendorf JJ, Kahler RA, Schroeder TM: Wnt signaling in osteoblasts and bone diseases. Gene 2004, 341:19-39.

42. Hartikka H, Mäkitie O, Männikkö M, Doria AS, Daneman A, Cole WG, AlaKokko L, Sochett EB: Heterozygous mutations in the LDL receptor-related protein 5 (LRP5) gene are associated with primary osteoporosis in children. J Bone Miner Res 2005, 20:783-789.

43. Ferrari SL, Deutsch S, Choudhury U, Chevalley T, Bonjour JP, Dermitzakis ET, Rizzoli R, Antonarakis SE: Polymorphisms in the low-density lipoprotein receptor-related protein 5 (LRP5) gene are associated with variation in vertebral bone mass, vertebral bone size, and stature in whites. Am J Hum Genet 2004, 74:866-875.

44. van Meurs JB, Rivadeneira F, Jhamai M, Hugens W, Hofman A, van Leeuwen JP, Pols HA, Uitterlinden AG: Common genetic variation of the low-density lipoprotein receptor-related protein 5 and 6 genes determines fracture risk in elderly white men. J Bone Miner Res 2006, 21:141-150.

45. Akhter MP, Wells DJ, Short SJ, Cullen DM, Johnson ML, Haynatzki GR, Babij P, Allen KM, Yaworsky PJ, Bex F, Recker RR: Bone biomechanical properties in LRP5 mutant mice. Bone 2004, 35:162-169.

46. Sawakami K, Robling AG, Ai M, Pitner ND, Liu D, Warden SJ, Li J, Maye P, Rowe DW, Duncan RL, Warman ML, Turner CH: The Wnt co-receptor LRP5 is essential for skeletal mechanotransduction but not for the anabolic bone response to parathyroid hormone treatment. J Biol Chem 2006, 281:23698-23711.

47. Armstrong DW III, Rue J-PH, Wilckens JH, Frassica FJ: Stress fracture injury in young military men and women. Bone 2004, 35:806-816.

48. Lau HHL, Ng MUM, Ho AYY, Luk KDK, Kung AWC: Genetic and environmental determinants for bone mineral density in Chinese women. Bone 2005, 36:700-709.

49. Guo Y-F, Xiong D-H, Shen $H$, Zhao L-J, Xiao P, Guo Q, Wang W, Yang T-L, Recker RR, Deng H-W: Polymorphisms of the low-density lipoprotein receptor-related protein 5 (LRP5) gene are associated with obesity phenotypes in a large family-based association study. J Med Genet 2007 43:798-803.
50. Santtila M, Kyröläinen $H$, Vasankari T, Tiainen S, Palvalin K, Häkkinen A, Häkkinen K: Physical fitness profiles in young Finnish men during the years 1975-2004. Med Sci Sports Exerc 2006, 38:1990-1994.

doi:10.1186/1471-2156-11-95

Cite this article as: Korvala et al: Genetic predisposition for femoral neck stress fractures in military conscripts. BMC Genetics 2010 11:95.

\section{Submit your next manuscript to BioMed Central and take full advantage of:}

- Convenient online submission

- Thorough peer review

- No space constraints or color figure charges

- Immediate publication on acceptance

- Inclusion in PubMed, CAS, Scopus and Google Scholar

- Research which is freely available for redistribution

Submit your manuscript at www.biomedcentral.com/submit

Ciomed Central 